This is a self-archived version of an original article. This version may differ from the original in pagination and typographic details.

Author(s): Toivanen, Juhana

Title: Perceiving As : Non-conceptual Forms of Perception in Medieval Philosophy

Year: 2020

Version: Accepted version (Final draft)

Copyright: @ 2020 Koninklijke Brill NV, Leiden

Rights: In Copyright

Rights url: http://rightsstatements.org/page/lnC/1.0/?language=en

Please cite the original version:

Toivanen, J. (2020). Perceiving As : Non-conceptual Forms of Perception in Medieval Philosophy. In E. Băltuță (Ed.), Medieval Perceptual Puzzles : Theories of Sense Perception in the 13th and 14th Centuries (pp. 10-37). Brill. Investigating Medieval Philosophy, 13.

https://doi.org/10.1163/9789004413030_003 


\title{
Perceiving as: non-conceptual forms of perception in medieval philosophy
}

\author{
Juhana Toivanen (University of Gothenburg)
}

\begin{abstract}
This chapter focuses on thirteenth-century Latin discussions concerning the psychological processes that explain some of the most sophisticated features of perceptual experience. Sense perception primarily conveys information about the sensible qualities of external objects; we see colours, hear sounds, taste flavours, and so forth. Yet, our experience of the external world contains several elements that cannot be reduced to these qualities. To name a few, external objects are perceived as threedimensional bundles of properties, as useful or harmful for the perceiving subject, and as objects of desires, fears, and other emotions, and they are conceptualised in various ways-in short, they are perceived as something.

It is well known that medieval philosophers recognised these and other similar phenomena. They analysed various elements of perceptual experience, which are not (or cannot be) directly apprehended by the external senses. In order to account for these elements, they argued that in addition to the five external senses, several so-called internal senses contribute to perception. The leading idea in their approach was to divide complex psychological processes into sub-processes or functions that can then be attributed to various internal senses, and analysed separately.

An analysis of medieval views from the perspective of the interplay between external and internal senses allows us to understand the complexity of perceptual experience. This chapter will (1) specify different types of 'perceiving as' that medieval authors recognised, (2) explain what kind of additions these processes make to perception, (3) suggest two heuristic models that can be used to analyse medieval theories, and (4) ask where the limit between conceptual and non-conceptual perception lies.
\end{abstract}

\section{Introduction}

Sense perception primarily conveys information about the sensible qualities of external objects; we see colours, hear sounds, taste flavours, and so forth-at least if we accept a (naïve) realist conception of perception. Yet, our experience of the external world contains several elements that cannot be reduced to these qualities. To name but a few, external objects are perceived as three-dimensional things that exist in time, as synthetic wholes that are composed of various properties, as useful or harmful for the perceiving subject, and as objects of desires, fears, and other emotions, and they are conceptualised in various ways-in short, they are perceived as something.

The aim of the present chapter is to take a closer look at medieval discussions concerning the phenomenon of 'perceiving as', and the psychological mechanisms that lie behind it. Nowadays, this notion is usually used to refer to conceptual aspects of perception. For instance, when I perceive a black birdlike shape as a crow, I may be said to perceive the particular sensible thing $x$ as an instance of a universal crowness $\varphi$, that is, as belonging to a natural kind and falling under the concept of 'crow'. In this sense, 
perceiving $X$ as $\varphi$ requires mastering the concept $\varphi .^{1}$ However, I use the term perceiving-as in a wider sense and concentrate on various kinds of non-conceptual sensory processes, which can be understood as forms of perceiving-as. ${ }^{2}$ Even though conceptual perception requires intellectual powers, medieval discussions on cognitive psychology can be understood properly only by taking into account the complex forms of perception that fall short of being truly intellectual, but are over and above the simple sensations of the sensible qualities of external things. The borderline between simple sensation and conceptual perception is unclear, and quite a lot is going on in the grey area between the two. Instead of presupposing a modern notion of perceiving-as and applying it to medieval discussions, my purpose is the opposite: to look at medieval discussions and see if they can be used to broaden the modern notion so as to include also non-conceptual varieties of perception.

I shall begin the analysis in Section two by specifying the various types of cognitive processes that were discussed by medieval authors and can be considered as forms of perceiving-as. The bulk of the historical work will be done in Section three, where I focus on medieval discussions on three interrelated cognitive functions-perceiving different sensible qualities as a synthetic whole, incidental perception of one sensible quality through another, and the possibility of perceiving substances and recognising individuals. In Section four, I propose two theoretical models that can be used for analysing medieval views concerning these psychological phenomena. Finally, I conclude the chapter by making some remarks on the potential impacts of reading medieval views in relation to the concept of perceiving-as.

\section{Varieties of Perceiving-as}

Medieval authors discussed various kinds of psychological processes that together provide a complex perceptual experience. This was done in the context of faculty psychology in which the so-called internal senses played a central role. The number of internal senses and the details of their functions varied from author to author, but the basic principle remained rather stable-each more or less well-defined psychological function was attributed to a distinct power of the soul. Just like the five external senses are distinct powers that have their proper functions, and one may lose one of them without losing others (there are animals that lack sight but are able to hear), the sensory soul includes higher cognitive powers that are in this sense independent of each other. ${ }^{3}$

\footnotetext{
1 This conception of perceiving-as has been applied also to medieval theories. For instance, Eleanor Stump has argued that Aquinas' theory of cognition contains a distinction between seeing and seeing as, and that the latter is possible only because the intellect penetrates sensory cognition (Eleonore Stump, Aquinas (London/New York: Routledge, 2003), 260-62).

2 Thus, the role of rationality in perception is set aside here, but this is just a methodological decision. The models for analysing medieval views, which are suggested below, can be applied to conceptual perception as well.

${ }^{3}$ In the following, I shall presume that the reader is familiar with the general aspects of medieval theories of the internal senses. The literature on them is voluminous; see, e.g. Nicholas $\mathrm{H}$. Steneck, The Problem of the Internal Senses in the Fourteenth Century, PhD Diss. (Ann Arbor, Michigan: UMI, 1970); Dag Nikolaus Hasse, Avicenna's De Anima in the Latin West: The Formation of a Peripatetic Philosophy of the Soul 1160-1300 (London/Turin: The Warburg Institute/Nino Aragno Editore, 2000); Carla di Martino, Ratio Particularis: Doctrines Des Senses Internes d'Avicenne À Thomas d'Aquin (Paris: Vrin, 2008).
} 
If we look at the various functions that medieval authors attributed to the internal senses, we can find at least six different cases in which a simple perception of a sensory quality turns into a more complex perceptual experience that can be called perceivingas:

(1) Perceiving several sensible qualities as forming a synthetic whole.

(2) Incidental perception of one sensible quality through another.

(3) Perceiving a certain individual.

(4) Perceiving something as harmful or useful.

(5) Perceiving temporal succession.

(6) Perceiving three-dimensionality.

These cases originate mostly in Aristotle and Avicenna, and they were widely discussed in the Latin tradition. Modern scholarship has concentrated especially on case (4), which is the main function of the estimative power. When one perceives an external object, the estimative power apprehends its relevance to the perceiving subject, and this explains the behaviour of the subject. Usually, this process was accounted for by appealing to insensible affective qualities, the so-called intentions (intentiones), that enter the cognitive apparatus of the subject together with the perceptual qualities of the object, even though they cannot be directly perceived. ${ }^{4}$ However, there were also philosophers who argued that intentions are not insensible properties of objects but rather are estimative judgements that affect the way external objects are perceived. ${ }^{5}$ Further, perception of temporal succession (case (5)) was discussed in relation to Avicenna's examples of a raindrop appearing as a line as it falls from the sky and of a circle of fire that appears when a torch is whirled quickly around. Instead of seeing a series of still images of the raindrop and the torch, we see a line and a circle, and yet the external world does not contain the line and the circle. ${ }^{6}$ Likewise, although the external world is three-dimensional (case (6)), that aspect is not immediately present to the sense of sight. In principle, the world is seen as two-dimensional because both eyes receive a two-dimensional image of it. Three-dimensionality becomes a part of our perception only because the cognitive apparatus interprets these images in a certain

${ }^{4}$ See, e.g., Thomas Aquinas, Summa Theologiae, ed. P. Caramello (Turin: Marietti, 1948-50), 1.78.4; Thomas Aquinas, Quaestiones Disputatae de Anima, ed. B.-C. Bazán (Rome/Paris: Commissio Leonina/Les Editions du Cerf, 1996), q. 13; di Martino, Ratio Particularis, 85-101; Dominik Perler, "Why Is the Sheep Afraid of the Wolf? Medieval Debates on Animal Passions," in Emotion and Cognitive Life in Medieval and Early Modern Philosophy, ed. M. Pickavé and L. Shapiro (Oxford: Oxford University Press, 2012), 32-51.

${ }^{5}$ Alexander of Hales, Summa Theologica, vol. 2 (Florence: Collegium S. Bonaventurae, 1928), 1.2, q. 2, 436a; ibid, 438b; Petrus Ioannis Olivi, Quaestiones in Secundum Librum Sententiarum, ed. B. Jansen (Florence: Collegium S. Bonaventurae, 1922), q. 64, 602-7. For a discussion on Olivi, see Juhana Toivanen, Perception and the Internal Senses: Peter of John Olivi on the Cognitive Functions of the Sensitive Soul (Leiden/Boston: Brill, 2013), 327-39.

${ }^{6}$ Avicenna, Liber de Anima Seu Sextus de Naturalibus, ed. S. Van Riet, vol. IV-V (Louvain/Leiden: Éditions Orientalistes/Brill, 1968), 1.5, 88-89. For a discussion, see Jari Kaukua, "Avicenna on the Soul's Activity in Perception," in Active Perception in the History of Philosophy: From Plato to Modern Philosophy, ed. J.F. Silva and M. Yrjönsuuri (Dordrecht: Springer, 2014), 99-116. In addition, medieval philosophers discussed perception of time in relation to De sensu 7, 448a1930. See, e.g., Thomas Aquinas, Sentencia Libri De Sensu et Sensato, Sancti Thomae de Aquino Opera Omnia Iussu Leonis XIII P.M. Edita 45/2 (Rome/Paris: Commissio Leonina/Vrin, 1985), $1.17,94 a$. 
way. ${ }^{7}$ The most radical example of this interpretative activity is familiar to anyone who has ever been to an art museum. Paintings are two-dimensional flat surfaces but they are perceived as if they contained three-dimensional objects. Three-dimensionality is added to bare perception because we have learned that the real things that are represented in the painting are three-dimensional. ${ }^{8}$ These three cases can be considered as more complex ways of perceiving external sensible qualities, which are brought about by psychological processes in which the soul actively structures perceptual content by adding new elements to it. ${ }^{9}$

Although these three cases are highly interesting, it is not possible to analyse them further in this context. Instead, I shall focus on the first three cases in the list, which pertain to perception of sensible qualities and an individual substance that is the bearer of these qualities. These three cases have in common that they all are more or less complex ways of apprehending the real properties of external things. It seems at the outset that they do not involve any additional input from the soul, and that the cognitive apparatus does not need to actively structure the perceptual experience in relation to them. However, a closer look reveals that this initial impression is not altogether correct.

These cases can be considered as forms of non-conceptual perceiving-as (or so I claim), but it is far from clear that medieval philosophers consider them as such. They were understood as resulting from different psychological mechanisms, and this raises the question of whether they can be treated as instances of one psychological phenomenon that we call perceiving-as-especially because medieval authors did not use any single expression that could be identified with the modern notion of perceiving-as. It would be anachronistic to simply take the modern notion and apply it to different psychological processes in medieval psychology by using the sole criterion that these processes seem to fit what we are looking for.

There are two remarks that I want to make in relation to this methodological concern. First, I am not claiming that medieval authors would have considered these cases as instances of a single psychological phenomenon. Instead, by looking at medieval discussions on the psychological functions of the internal senses, we might find some insights that help us to rethink the modern notion of perceiving-as. After all, the modern notion is not unified and well defined either, and there is some room for developing it with the help of historical views as long as we distinguish our interpretations clearly from what medieval authors wrote and meant. This kind of rethinking does not presuppose any strong unity of the psychological functions that figure in medieval theories. Second, for reasons that will become clear below, it seems to me that the different kinds of psychological processes listed above do have a sort of unity, which makes it reasonable to consider them together. Namely, they are all processes that modify and enrich our perceptual experience of the external world. If we suppose (at this point simply for the sake of argument) that there is a unified perceptual experience

7 For a discussion concerning different historical models, see Mikko Yrjönsuuri, "Seeing Distance," in Silva \& Yrjönsuuri (eds.), Active Perception, 187-206.

8 This example is presented in Olivi, Summa II, q. 73, 99. To be sure, it is not completely clear that seeing a painting and seeing the world as three-dimensional are based on the same mechanism.

${ }^{9}$ It would be tempting to say that these ideas resemble the Kantian approach, but there is at least one crucial difference; while medieval authors acknowledged that the soul structures the perceptual content, they argued that it only grasps the world as it is in reality. 
that emerges from the joint action of different powers, the ways in which this experience is modified have the intended kind of unity, even if a detailed analysis shows that there are important differences in the psychological and physiological mechanisms that brings it about.

\section{Perceiving Sensible Qualities and Individual Substances}

Synthetic Wholes

Let us now turn to the psychological processes that enrich the perceptual experience. As I already mentioned, each of the five external senses has its proper object, the sensible qualities of colour, sound, flavour, and so forth. When I see a crow, I see directly its black colour and nothing else. However, if the crow happens to be cawing, I also hear its voice. These two proper sensibles are connected in my experience in such a way that I perceive a black thing that is cawing. (Or to be exact, I perceive this-black that makes this-cawing-sound; whether or not I perceive the substance behind these accidental qualities is another matter. $)^{10}$

In the framework of faculty psychology, the unified experience of different sensory qualities requires an explanation. Colours cannot be heard and sounds cannot be seen, and thus there has to be some single power that apprehends both. Medieval philosophers answered to this problem - nowadays known as 'the binding problem'by attributinged the unifyingis function to the common sense. ${ }^{11}$ The information from the external senses is transmitted to the common sense, which functions as a centre where a unified bundle of properties is formed:

The proper sensibles are united in the common sense. For, if there was nothing in us where whiteness and sound were united, we would not know that the thing, the sound of which we hear, is white. The unity of whiteness and sound is apprehended neither by the eyes nor by the ears, but by the common sense. ${ }^{12}$

${ }^{10}$ Aristotle speaks about perception of white and sweet, and he focuses mainly on the ability to tell the difference between the two. Some medieval authors thought that The the white and sweet substance inof Aristotle's the example is was, at least according to some of Aristotle's medieval readers,-milk: "Item, sicut album et dulce in lacte sunt idem subiecto et differunt formaliter, sic dicunt de sensu communi." (Anonymous, Quaestiones Super Librum De Sensu et Sensato, Paris, BNF Ms. lat. 16160, q. 37, 118va.) In contrast, Albertus Magnus mentionsrefers to sugar: "ut album et dulce in zuc[c]aro" (Albertus Magnus, De Homine, ed. H. Anzulewicz and J.R. Söder (Aschendorff: Monasterii Westfalorum, 2008), q. 35, a. 1, 269.) $\div 0$ 0n the history of sugar in medieval Europe, see Sidney W. Mintz, Sweetness and Power: The Place of Sugar in Modern History (New York: Penguin Books, 1986), 19-32; Elizabeth Abbott, Sugar: A Bittersweet History (London/New York: Duckworth Overlook, 2008), 11-27.) For a recent study on Aristotle, wich shows a similar preoccupation with the contents and structures of perceptual experience as the present essay, see Anna Marmodoro, Aristotle on Perceiving Objects (Oxford: Oxford University Press, 2014). // Hobhouse, Seeds of change, 45, Mintz Sidney, Sweetness and power: the place of sugar in modern history, 25, 28, 243-44 n52 [PDF / GU library]; Galloway, The sugar cane industry, 25:

11 See, e.g., Averroes, Long Commentary on the De Anima of Aristotle, trans. Richard C. Taylor (New Haven/London: Yale University Press, 2009), 2.146, 267-8.

12 "[...] sensus communis est, in quo coniunguntur sensata propria. Si enim nihil esset in nobis, in quo coniungerentur albedo et sonus, nesciremus hoc album esse, cuius sonum audivimus. Coniunctionem vero albedinis et soni non apprehendit oculus nec auris, sed sensus communis." (Albertus Magnus, De Homine, ed. H. Anzulewicz and J.R. Söder (Aschendorff: Monasterii 
At the outset, it might seem that this process cannot be considered as a type of perceiving-as. After all, there does not seem to be any additional information over and above the perception of colour and sound. Unifying them does not require classification or interpretation; we just perceive a colour and a sound in connection to each other.

However, a closer inspection shows that the process provides the perceiver with information that is not trivial. It is one thing to perceive two distinct qualities, colour and sound, but it is quite another to perceive them as forming a synthetic whole. The black colour is perceived as a part of the same bundle as the cawing sound and vice versa, and it is precisely the connection between the two qualities, the unity of the two, that can be considered as perceiving-as. The process that brings about this connection is a real addition, because the unity is not obvious. It is possible to imagine a subject that lacks the ability to perceive different qualities as connected to each other. Her perceptual experience would thus differ radically from normal perception.

The idea that different sensible qualities are perceived as unified synthetic wholes suggests that perception is structured from the very beginning. We perceive the world as divided into separate objects and individual substances. This is to be expected on the basis of medieval acceptance of the idea that the world is divided into individual substances. The black colour and the cawing belong to one and the same substance, the crow, and they form a unity in our experience because that unity is a part of reality. However, the five external senses perceive the sensible qualities of these substances separately-in a way, the cognitive apparatus starts by dismantling particular objects into different kinds of accidental qualities. One would expect medieval authors to offer a philosophical explanation for the consequent re-assembly into structured substances or synthetic wholes, which include those properties that belong to a certain substance and exclude all the others. When I have the visual-auditory experience of the crow, I perceive a black cawing thing, but I do not attribute to it any other sensory qualities, such as the fresh smell of the forest, or the gentle feeling of raindrops on my skin. I can perceive these qualities simultaneously with the colour and sound of the crow, but they do not become associated with the crow.

To the best of my knowledge, medieval philosophers do not give an explanation for this bundling of properties; or they do, but only by explaining how the originally unified whole is assembled again in the cognitive apparatus. They fail to explain why all of the properties of a certain substance, and only those, are united in our experience. The reason for their neglect may be the underlying realistic conception of the relation between the world and our perception of it. The sensory qualities of the crow belong to one substance in reality, and therefore the fact that they appear to us as a unified whole is only natural..$^{13}$ To be sure, this does not explain why they merge in the psychological apparatus; it just explains why medieval authors did not raise the question. ${ }^{14}$

Westfalorum, 2008), q. 35, a. 2, 271.) For later discussions on this function, see Henrik Lagerlund, "Awareness and Unity of Conscious Experience: Buridan on the Common Sense," in Questions on the Soul by John Buridan and Others: A Companion to John Buridan's Philosophy of Mind, ed. G. Klima (Dordrecht: Springer, 2017), 149-56; Juhana Toivanen, "Peter Olivi on Internal Senses," British Journal for the History of Philosophy 15:3 (2007): 427-54.

13 When Albertus Magnus argues that two qualities must be perceived simultaneously, because they are simultaneously present in the object, he notes tersely that: "Iudicium autem est secundum quod res est." (Albertus Magnus, De Anima, ed. C. Stroick (Aschendorff: Monasterii 
The process in which the common sense bundles sensible qualities together is not infallible, however. The Aristotelian maxim states that external senses cannot err in their perceptions, but the more complex forms of sense perception are susceptible to error. For instance, Albertus Magnus argues that:

However, in composing the sensibles, there is frequently a great deception: for instance, what the coloured thing is (whether a golden-yellow thing is honey or yellow bile); or where the coloured thing is; or what it is that makes a sound; or where it sounds; and so with the others. I will explain below that the reason for this is that the combining does not belong to external sense but to some higher power, which makes the mistake. ${ }^{15}$

Most of these mistakes are related to the so-called common sensibles and incidental perception (see below), but not all. The "what it is that makes a sound" clearly stands for the ability to connect a certain sound with other sensible qualities that are perceived at the same moment-the connection between the cawing and the black colour, for instance. Albertus admits here that the unifying function of the common sense often fails to make veridical bundles of the accidental qualities of objects. The possibility of error underlines that the process adds something over and above the simple perception of distinct sensible qualities. Perceiving black colour as a colour of a thing that also makes a cawing sound is a process that enriches the perceptual experience in a significant and non-trivial way. Occasionally this aspect fails or is missing, and the resulting experience is radically different in comparison to cases where it is present. It is therefore clear that the unity that the common sense brings to perception is a real addition to, or modification of, the simple perception of singular qualities, and as such it can be called perceiving-as in a wide (non-conceptual) sense. It introduces structure into perceptual experience by allowing the perception of two qualities as belonging to the same synthetic whole.

\section{Incidental Perception}

A closely related type of non-conceptual perceiving-as is what medieval philosophers called accidental perception (incidental perception in modern parlance). Aristotle's examples of this process include perceiving bile as bitter without tasting it and

Westfalorum, 1968), 2.4.10,162.) Another possibility is that the intentio of the crow functions as a kind of a proto-concept that unifies the different sensible qualities together (see below).

${ }^{14}$ It is notable that when medieval philosophers analyse perception, they usually do not think of a process by which we come to apprehend the whole surrounding world; they have a tendency to consider the perception of objects, not that of a visual field. This approach sets the problem aside because the focus is not on the simultaneous perception of qualities that belong to several objects. See, e.g., Aquinas, Sentencia Libri De Sensu, 16, 90a-91b. Even some versions of extramissive theories were thought to hold that the base of a visual cone is one object, not the whole visual field (Albertus Magnus, De Sensu et Sensato, ed. A. Borgnet, B. Alberti Magni Opera Omnia 9 (Paris: Vivès, 1890), 1.5, 9a-b). The ability to perceive several things simultaneously was discussed in relation to Aristotle's De sensu, but the fact that the question was raised shows that it was something of an anomaly for the general theory. See, e.g. Aquinas, Sentencia Libri De Sensu, 16-18, 90a-101b.

15 "In compositione tamen sensibilium magna frequenter est deceptio, sicut quid est quod est coloratum, ut utrum croceum sit mel aut cholera citrina aut ubi est coloratum aut quid est, quod sonat, aut ubi sonat, et sic de aliis. Et causam huius infra dicemus esse quoniam sensus proprius non habet componere, sed aliqua superior potentia, et illius est error." (Albertus Magnus, De Anima, 2.3.5, 103.) 
perceiving bile as honey due to the similarity of their colours. Avicenna elaborates on these examples, and Latin authors by and large follow his view. ${ }^{16}$ The central idea in the example is that when we perceive one sensible quality (yellow), we often apprehend it in such a way that a sensible quality of some other sense modality (sweet taste) figures in our perceptual experience, even if we do not taste sweetness at the moment. In the words of John of la Rochelle:

Note, therefore that there are per se sensible and accidentally sensible things. The accidentally sensible things are when an object of one sense is said to be perceived by another, as when it is said that sweetness of an apple is seen. This is accidental perception, because the sweetness is an object of the sense of taste. It is said to be seen accidentally, that is, through another (namely, through the red colour of the apple); the sweetness is perceived per se and properly only by the sense of taste. ${ }^{17}$

The result of this process can be considered to be a form of perceiving-as. When we see a red apple or a jar full of yellow substance, we see nothing but a colour that has a certain shape. But if incidental perception takes place, we see the red as having the taste of an apple and the yellow colour as sweet (if we see it as honey) or as bitter and repulsive (if we see it as yellow bile).

Now, one might have a problem with the idea that the taste of honey is seen. It would be more precise to say that when the colour of honey is seen, the perceiver becomes aware of a synthetic whole that also includes other sensible qualities of honey. Supposedly the experience is not similar to actually tasting honey, but closer to imagining sweetness. After all, the sensible qualities are stored in the imaginative power, and they are evoked from there when the yellow colour of honey is seen. Medieval authors clearly accepted the idea that some kind of cognition (or awareness) of sweetness takes place, and they were usually happy to say that the taste is seen, but probably this was just a way to emphasise that the incidental seeing of sweetness is distinct from imagining sweetness.

Incidental perception is a part of perceptual experience. By this I mean that when medieval authors say things like "we say that we see bitter when we see yellow," 18 they are not referring just to an objective fact (i.e., that the yellow thing we see happens to be bitter), but also and perhaps mainly to a subjective experience-bitterness figures in our experience. Although this is not always made explicit, many texts leave little room for doubt. For instance, Albertus Magnus continues soon after the previous quotation by referring to a subjective experience: "often when one grasps yellow, one thinks that it is bitter." 19 Moreover, the process takes place on the sensory level and does not involve intellectual powers. It is a non-conceptual form of perceiving-as. The yellow substance does not need to be conceptualised as honey, and one does not need to have a

${ }_{16}$ Aristotle, De anima 3.1, 425a30-b4; Sophistical Refutations 5, 167b4-5. Avicenna, Liber de Anima 4.1, 7-8. For a recent analysis of Avicenna's position, see Kaukua, "Avicenna on the Soul's Activity," 99-116.

17 "Nota ergo quod est sensibile per se et sensibile per accidens. Sensibile per accidens est, cum obiectum unius sensus dicitur percipi ab alio, ut dulce in pomo cum dicitur uideri. Iam hoc est per accidens, quia dulce est obiectum gustus. Dicitur tamen uideri per accidens, id est per aliud, scilicet per colorem coccineum pomi; per se tamen et proprie dulce non percipitur nisi gustu." (John of la Rochelle, Summa de anima, ed. J.G. Bougerol (Paris: Vrin, 1995), 2.94, 236-7.)

18 "[...] dicimus nos videre amarum, quando videmus citrinum [...]" (Albertus Magnus, De Anima, 2.4.6, 156.)

19 "[...] saepe cum accipit citrinum hoc ipsum putat esse amarum" (Albertus Magnus, De Anima, 2.4.6, 156.) 
propositional belief that it is honey in order to perceive it as sweet, because these would require mastering the concept of honey, knowing the essence of honey, and so forth. Thomas Aquinas famously argues that there is a radical difference between the way rational human beings and irrational animals perceive the world around them. ${ }^{20}$ Only human beings have a cogitative power, which enables apprehending things "as existing under a common nature", because this power has an intrinsic connection to the intellect. Supposedly Aquinas means that humans can perceive individual things as members of natural kinds and as instances of universals. Thus, conceptualising and classifying the perceived yellow thing as honey requires rationality, but the incidental perception of honey as sweet does not. ${ }^{21}$

This point can also be seen in the following argument, which Dominicus Gundissalinus copies almost verbatim from Avicenna's Liber de anima:

[...] if these <qualities > were not connected in the imagination of animals (which lack the intellectual power), they would not desire to eat a thing which has a certain shape and is sweet when they see it, although they are inclined by their own desire to sweetness. [...] Likewise, if animals did not have a power where the forms of perceptible things are connected, it would be difficult for them to live-namely, if smelling did not reveal taste, and if sound did not reveal taste, and if the form of a stick did not remind of a form of pain so that one flees from it. There is no doubt, therefore, that these forms must have some one internal thing where they are connected.22

Gundissalinus clarifies that the power that provides the required unity is the common sense. ${ }^{23}$ The basic idea of his argument is that animals desire to eat sweet things, and the

20 Thomas Aquinas, Sentencia Libri De Anima, Sancti Thomae de Aquino Opera Omnia Iussu Leonis XIII P.M. Edita 45/1 (Rome/Paris: Commissio Leonina/Les Editions du Cerf, 1984) (hereafter Sent. $D A$ ), 2.13, 121b-22b. A useful discussion and references can be found in Anselm Oelze, Theories of Animal Rationality in the Later Middle Ages, PhD Diss. (Humboldt-Universität zu Berlin, 2016), 46-55. Robert Pasnau writes that: "Whereas we perceive a world full of familiar kinds of objects, animals must lack this level of conceptualization. They see objects, perhaps, but do not see them as members of kinds." (Robert Pasnau, Thomas Aquinas on Human Nature: A Philosophical Study of Summa Theologiae Ia 75-89 (Cambridge: Cambridge University Press, 2002), 271; see also Anthony J. Lisska, Aquinas's Theory of Perception: An Analytic Reconstruction (Oxford: Oxford University Press, 2016), 249-54.)

${ }^{21}$ Aquinas thinks that incidental perception, properly speaking, applies only to properties that are imperceptible by themselves. He is stricter than many others, who claim that we may speak of incidental perception also in cases where one of the sensible qualities is not perceived directly at the moment. See Sent. DA, 13, 120b-21a; Lisska, Aquinas's Theory of Perception, 239-42. Two different kinds of incidental perception: see, e.g., Albertus Magnus, De Anima, 2.4.6, 155; Averroes, Long Commentary on the De Anima, 2.134, 255-56.

${ }_{22}$ "Si enim non coniungerentur in imaginatione animalium quae carent intellectu, cum inclinarentur proprio desiderio ad dulcedinem, scilicet quod res quae est huiusmodi formae est dulcis, cum viderent eam non appeterent eam ad comedendum. [...] Item, si non esset in animalibus virtus in qua coniungerentur formae sensatorum, difficile esset eis vivere, scilicet si olfactus non ostenderet saporem et si sonus non ostenderet saporem et si forma baculi non rememoraret formam doloris ita ut fugiatur ab eo. Oportet igitur sine dubio ut formae istae habeant unum aliquid in quo coniungantur intrinsecus." (Dominicus Gundissalinus, Tractatus de Anima, ed. J.T. Muckle, in "The Treatise De Anima of Dominicus Gundissalinus," Mediaeval Studies 2 (1940): c. 9, 72.) The passage is taken from Avicenna, Liber de Anima 5.1, 2-3.

${ }^{23} \mathrm{He}$ argues that the imaginative power is nothing but a storehouse of sensory forms, and it does not provide any awareness of its contents. See Gundissalinus, Tractatus de Anima, c. 9, 72-3. There is a considerable fluctuation concerning the attribution of incidental perception to one of 
perception of sweetness explains why they pursue certain objects around them. A desire for a certain thing arises only if it is perceived as sweet. We can easily observe that animals often seek things that they are not tasting at the moment. This proves that they are capable of perceiving distant objects as sweet-they incidentally perceive sweetness when they see something that is suitable for their nourishment. Because animals lack reason, however, the process cannot be a rational one.

If the yellow substance is not categorised as honey, what kind of perceptual content does incidental perception bring about? If perception does not include any recognition of what the yellow thing is, how does it evoke the perception of sweetness? One possibility is that non-conceptual perception of yellow as sweet is based on association. A perception of yellow stuff just happens to evoke the form of sweetness in the imaginative power, and no further explanation can be given. Another possibility is that the imaginative power does not store isolated sensible qualities but bundles of several qualities; after all, it was considered to be the storehouse for the representations that the common sense brings about, and unifying different sense modalities was one of the functions of the common sense. The process would still be associative, but one that can be explained by earlier experiences. When one sees and tastes honey, the two qualities are unified in the common sense and then stored in the imagination together. Subsequent perception of one of these qualities evokes the complex representation, including the other qualities.

However, there are many yellow things that are not apprehended as sweet, and they do not evoke the incidental perception of sweetness. It seems likely that dissimilar reactions towards different yellow things might be explained simply by appealing to differences in visible qualities of yellow things. If the visible qualities of the representation of honey, which is stored in the imagination, differ from the visible qualities of other representations, the explanation for different reactions upon seeing different yellow things is at hand.

Medieval authors do not take this route, however, probably because they acknowledge that incidental perception can be mistaken. ${ }^{24}$ Sometimes the very same yellow substance is apprehended as sweet, sometimes as bitter. This suggests that there is a third option; the yellow substance needs to be recognised as honey before sweetness is attributed to it. It has been suggested that Avicenna's theory presupposes that the process is inferential in this sense. The yellow substance is seen as sweet, because it is seen as honey. 25 The estimative power "recognises" the yellow substance as what it isas a substance that is both yellow and sweet-and the incidental perception of sweetness arises on the basis of this recognition. The intentio of honey functions as a "proto-concept" that holds different sensible qualities together in one representation and triggers the incidental perception of sweetness. The intentio in this case is not an insensible affective quality on par with harmfulness or usefulness. Instead, it is some

the internal senses. The common sense, imagination, estimative power, and cogitative power all have their defenders.

${ }^{24}$ See, e.g., Albertus Magnus, who claims that: “[...] quaecumque virtus comparat inter sensata plurium, oportet, quod accipiat sensata plurium; et hoc non potest facere aliquis sensus proprius. Et quia hoc non est proprium alicuius sensus particularis, ideo frequens fit deceptio circa hoc [...] quia saepe, cum accipit citrinum, hoc ipsum putat esse amarum, et ita mel aliquando opinatur esse fel." (Albertus Magnus, De Anima, 2.4.6, 156.)

25 Kaukua, "Avicenna on the Soul's Activity," 106-11. 
kind of non-conceptual representation that functions as the basis for unifying different sensible qualities into a synthetic whole. ${ }^{26}$

Given that this process takes place at the sensory level and can be attributed to nonhuman animals, it must be non-conceptual (or perhaps pre- or proto-conceptual) in the sense, to use Aquinas' expression, that it does not enable perceiving the individual object under a common nature. However, the psychological mechanism that underlies this experience requires recognising "this-yellow-stuff-that-is-sweet." It is difficult to see how else the incidental perception of sweetness could come about, especially in those cases in which the same sensible quality may be connected to different incidentally apprehended qualities. ${ }^{27}$

It is not easy to see how this apprehension falls short of conceptualisation, because medieval authors do not address the issue in so many words. However, the distinction between conceptual apprehension of honey as honey, and the perceptual process of perceiving honey as this-foul-tasting-stuff, was occasionally taken up. Gundissalinus claims, following Avicenna, that:

The estimation is the more excellent judge in animals. It judges according to the invention of the imagination when it is not certain, just like when a human being thinks that honey is foul because it is similar to excrement. For, the estimation judges that it is so, and the soul follows the estimation even though the intellect disapproves. ${ }^{28}$

${ }^{26}$ Albertus Magnus uses the term intentio precisely in the sense that it signifies the individual thing as such: "Intentio autem vocatur id per quod significatur res individualiter vel universaliter secundum diversos gradus abstractionis; et haec non dat esse alicui nec sensui, quando est in ipso, nec etiam intellectui, quando est in illo, sed signum facit de re et notitiam. [...] Et ideo intentio non est pars rei sicut forma, sed potius est species totius notitiae rei; et ideo intentio, quia abstrahitur de toto et est significatio totius, de re praedicatur." (Albertus Magnus, De Anima, 2.3.4, 102; Jörg Alejandro Tellkamp, "Albert the Great on Structure and Function of the Inner Senses," in The Judeo-Christian-Islamic Heritage: Philosophical \& Theological Perspectives, ed. R.C. Taylor and A.O. Irfan (Milwaukee: Marquette University Press, 2012), $316-$ 18; id., "Aping Logic? Albert the Great on Animal Mind and Action," in Subjectivity and Selfhood in Medieval and Early Modern Philosophy, ed. J. Kaukua and T. Ekenberg (Dordrecht: Springer, 2016), 119-20.) Medieval philosophers argued that memory preserves intentiones apprehended by the estimative power. At the same time, memory was thought to remember, for instance, what a certain person did in a certain place at certain time, which suggests that intentiones represent something more than just affective features such as harmfulness. See John of la Rochelle, Tractatus de Divisione Multiplici Potentiarum Animae, ed. P. Michaud-Quantin (Paris: Vrin, 1964), 2.10, 76-77.

27 Gundissalinus, again following Avicenna to the letter, distinguishes two kinds of intentionsones that are insensible by their nature (e.g., harmfulness) and others that are sensible but not actually sensed at the moment. The latter are responsible for incidental perception: "Quae vero sunt sensibiles sunt sicut cum videmus aliquid ceruleum, iudicamus esse mel et dulce [...] virtus qua haec apprehenduntur est alia virtus et vocatur aestimativa." (Dominicus Gundissalinus, Tractatus de Anima, c. 9, 73.) Given that sweetness is not the kind of object that the estimative power apprehends, it seems that the role of estimation is to recognise the yellow substance as honey (this point is made in Kaukua, "Avicenna on the Soul's Activity," 108-9).

28 "Dicimus ergo quia aestimatio excellentior iudex est in animalibus quae iudicat ad modum adinventae imaginationis, cum non est certa sicut cum putat homo mel sordidum quia simile est stercori. Aestimatio enim iudicat ita esse et anima sequitur ipsam aestimationem quamvis intellectus improbet." (Dominicus Gundissalinus, Tractatus de Anima, c. 9, 77.) 
It is not altogether clear how this argument should be interpreted, especially the idea that "the intellect disapproves". Probably the point is that although the intellect does not approve the shunning from the yellow stuff, the person (or her anima) follows the estimative judgement to shun from it. In other words, there is a conflict between an intellectual consideration of what should be done, and an emotional reaction of the sensory part of the soul. ${ }^{29}$ Animals do not have any higher power to guide them, and therefore they necessarily follow estimative judgement, and some humans are similar to animals in this respect because they do not follow their reason. ${ }^{30}$ The crucial aspect of this argument is that the repulsion does not disappear even if one knows that the yellow substance is honey, and the conflict is also between perceptual judgement and an intellectual belief. ${ }^{31}$ The intellect has to make a cognitive judgement that the substance is honey, not excrement, because otherwise it would not question the judgement of the estimation. The repulsion remains, and thus the intellectual judgement that the yellow substance is honey does not overrule the non-conceptual misjudgement, the "recognition" of this-yellow-stuff-that-is-repulsive. If there were no intellectual judgement ("In fact, this is honey"), or if the intellectual judgement overruled the estimative judgement, the conflict would not arise. Whether the perceptual judgement is based on a proto-conceptual recognition of this-yellow-stuff that is excrement and foul (or bile and bitter), or just on the association between the sensible qualities of yellow and bitter, the fact remains that the level of perception is not directly affected by intellectual conceptualisation. Knowledge that the yellow substance is honey does not remove the repulsiveness. I still perceive it as repulsive excrement. $\underline{32}$

If this is on the right track, we can see that conceptualisation works on a different level and does not necessarily influence the perceptual content. ${ }^{33}$ Perception is not false in the sense that a yellow substance would be seen as something that it is not. It is seen as yellow. The mistake arises either when the imagination spontaneously evokes the incidental perception of bitterness (or some other foul taste), or when the estimation judges that the substance is excrement and causes the incidental perception of bitterness. The details of the process are unclear-that is, whether there is a need for "recognising" honey as this-yellow-sweet-substance, or whether incidental perception is associative and therefore more or less arbitrary. At least in the case of those medieval authors who emphasise the role of the estimative power when they describe the process, it seems likely that something more is at stake than simple association of various sensible qualities in the imagination. ${ }^{34}$ However, even attributing a role to the

29 Improbo has connotations to moral judgement, but also "to overrule an opinion or judgement".

${ }^{30}$ Dominicus Gundissalinus, Tractatus de Anima, c. 9, 77-78.

${ }^{31}$ Avicenna has been interpreted along these lines. See Hasse, Avicenna's De Anima, 137.

32 A more illustrative example concerns snakes: human beings tend to have what medieval authors would have called an estimative repulsion towards snakes. When someone sees a snake, he may know that the species to which it belongs is not dangerous. Although this knowledge may change the way he acts in the situation, it does not necessarily diminsh the estimative repulsion and fear.

33 This seems to entail that the intellect should be understood in terms of the "addition-model": see section four below.

${ }^{34}$ See, e.g., Dominicus Gundissalinus, Tractatus de Anima, c. 9, 73; John of la Rochelle, Summa de Anima, 2.4.101, 248.); Albertus Magnus, De Anima, 2.3.5, 104. For a discussion on Albertus, see Deborah Black, "Avicenna's 'Vague Individual' and Its Impact on Medieval Latin Philosophy," in Vehicles of Transmission, Translation, and Transformation in Medieval Textual Culture, ed. R. 
estimative power does not prove that proto-conceptual recognition takes place, and one might just hope that medieval authors would have been more precise when they wrote about incidental perception. It goes almost without saying that they might have had different opinions on the matter, and it is likely that at least some of them did not even consider the issue in such a detailed manner.

\section{Substances and Individuals}

This leads us to the third type of perceiving-as, namely perceiving one sensible quality or a synthetic whole of several qualities as a certain individual. Regardless of whether or not external objects need to be recognised as certain kinds of objects before incidentally perceiving the other qualities they possess, medieval authors occasionally discussed the ability to perceive substances as if "behind" the synthetic wholes of sensory qualities. They also acknowledged that even animals are capable of perceiving things as certain individuals-they have an ability to recognise this particular thing by their estimative powers. Let us briefly consider both of these.

Sense perception was thought to convey information only about the sensible (accidental) qualities of an external object. Substances, to which these qualities belong, cannot be perceived directly. I cannot see the crow because I see only its colour and shape. Already John Blund argues along these lines, but he also emphasises that substances can be perceived incidentally: "Qualities such as colours, tastes, heat, and cold are the proper sensibles of sensation. However, their subjects are not perceived through sensation except by accident." 35 William of Auvergne defends a similar position ${ }_{\cdot \bar{s}}$ and $\mathrm{hHe}$ emphasises that when we perceive the accidental qualities of external objects,

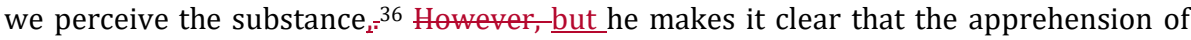
the substance behind the accidents requires rationality. ${ }^{37}$ It is possible to perceive this individual crow in addition to its sensible qualities, but apparently only if the intellect contributes to the cognitive process.

Perhaps the strongest support for the ability to perceive substances comes from Roger Bacon, who argues that: "[...] the claim that substances are not perceived by sense is to be understood with reference to a particular sense and the common sense and imagination; but it can easily be perceived by the estimation, which, although it is not called a sense, belongs none the less to the sensitive soul." 38 Bacon's motivation for attributing this ability to non-human animals is not altogether clear, ${ }^{39}$ but the most

Wisnovsky et al. (Turnhout: Brepols Publishers, 2011), 259-92; Tellkamp, “Aping Logic?”, 109_ 22.

35 "Qualitates, ut colores, sapores, caliditates, frigiditates, sunt propria sensata sensus. Subiecta autem illarum non apprehenduntur sensu nisi per accidens. Quod ergo proprie et per se cadit in sensum est qualitas." (John Blund, Treatise on the Soul, ed. D.A. Callus and R.W. Hunt, trans. M.W. Dunne (Oxford: Oxford University Press, 2013), 17, 124-25; emphasis mine.)

${ }^{36}$ William of Auvergne, De Anima, ed. F. Hotot (Paris: Andreas Pralard, 1674; reprint Frankfurt: Minerva, 1963); id., The Soul, trans. R.J. Teske (Milwaukee: Marquette University Press, 2000). 37 William of Auvergne, De Anima 5.18, 143; ibid., 7.1, 203 (The Soul, 257; 424).

38 "Quod igitur dicitur quod substantie non sentiuntur a sensu intelligendum est quod a sensu particulari et communi et ymaginatione; sed bene potest sentiri ab estimatione, que, licet non dicatur sensus, est tamen pars anime sensitive." (Roger Bacon, Perspectiva, ed. \& trans. D.C Lindberg, in Roger Bacon and the Origins of Perspectiva in the Middle Ages (Oxford: Clarendon Press, 1996), 1.1.4, 14-15.)

39 It may be noted that Albertus Magnus occasionally claims that the perception of "the subject" in which various sensible properties are united is necessary in order to actually apprehend 
important thing to note here is that those authors who emphasise the ability to apprehend the substance in one way or another seem to take seriously the common experience that we (and perhaps other animals) perceive things, not bundles of qualities. I see the crow and a cat sees this-black-something, instead of seeing only a black shape. Because direct perception pertains only to accidental qualities, the cognitive apparatus adds to the perception and turns it into a more complex experience, which might be called perceiving-as.

As for the recognition, there is an abundance of texts that deal with the ability to perceive individual things as individuals. It goes without saying that perception is always about individuals; only intellectual powers are capable of cognising universals. The crucial question is whether perception allows recognising a certain individual in distinction to others (of the same species). The Aristotelian idea that we are able to recognise individual human beings as sons and daughters of other individualsperceiving something white as the son of Diares-is a prime example of this ability. One or several sensible qualities are perceived, and through these the person is recognised as a certain individual. Although recognition of a certain person was often thought to be an intellectual process, ${ }^{40}$ or as a sensory process that needs input from the reason, we find similar processes in non-human animals.

It may be an exaggeration to say that all thirteenth-century philosophers attributed the ability to perceive individuals to irrational beings, but there is no denying that it was widely accepted that animals can do this. The estimative power was thought to be responsible for apprehending harmfulness and usefulness and thus triggering emotional reactions that enable animals to avoid harms and acquire useful things. In addition, Latin authors repeatedly argued that the estimative power allows animals to recognise individuals. A sheep recognises its lamb and vice versa, a dog recognises its master, and so forth. The animal in the example changes, but the overall idea remains the same. In Albertus' words: "[...] and a wolf would never feel compassion for its offspring, unless it cognized [1] that particular individual, and [2] that this individual is its offspring." 41 The wolf is able to distinguish its own cub from other things and also from other members of the same species, just by perceiving certain accidental qualities and by incidentally perceiving the substance behind them. ${ }^{42}$

these properties as bundled together-and that this ability belongs to the common sense. "Acceptio autem sensus particularis non est nisi sensibilis proprii sicut coloris vel vocis vel odoris vel alicuius alterius. Acceptio autem sensus communis est subiecti, in quo uniuntur sensata propria, et ideo componit et dividit sensata propria dicens hoc album esse dulce et hoc croceum esse amarum sicut fel." (Albertus Magnus, Physica, Libri I-IV, ed. P. Hossfeld (Aschendorff: Monasterii Westfalorum, 1987), 1.1.6, 11.) Cf. "Non enim accipitur per visum notitia coloris tantum, sed colorati, et species eius in visu species est colorati, secundum quod coloratum est, et iudicium fit de colorato, secundum quod coloratum est. Et sic est de aliis intentionibus, in quocumque gradu abstractionis accipiantur." (Albertus Magnus, De Anima, 2.3.4, 102.)

${ }^{40}$ See, e.g. Averroes, Long Commentary on the De Anima, 2.134, 255-6.

41 "[...] nec unquam lupus miseretur nato suo, nisi habeat cognitionem et huius individui et quod hoc individuum est natus eius." (Albertus Magnus, De Anima, 3.1.2, 167.)

${ }^{42}$ See also: "Sed secundum accidens sensibile est, quod propriam essentiam in sensum non imprimit nec primo nec secundo, sed cum sensibili proprio et communi accipitur, et non sine aestimatione vel cogitatione, sicut sunt intentiones, de quibus in tertio gradu abstractionis diximus, sicut quod hoc album est Diarii filius vel hoc nigrum est amicus vel homo vel animal, 
The capacity to perceive substances is not necessary for being able to recognise an individual, however. Even if one perceives only bundles of properties, one might still be able to recognise one bundle and distinguish it from others. For instance, John Blund argues that animals can recognise individual things and distinguish them from other things, but because they lack reason, they cannot pass a conceptual judgement that the thing they are perceiving belongs to a certain class of things-they distinguish but do not discern. ${ }^{43}$ Likewise, as mentioned above, Aquinas distinguishes human beings from other animals by claiming that only humans are capable of conceptual perception. Animals do not perceive things in their surroundings as belonging to natural kinds because they do not grasp universal concepts that would enable recognising them as the things they are. Instead, they perceive external things as objects or causes of their actions or emotions. ${ }^{44}$ This does not mean that animals would not be able to perceive other animals as somehow distinct individuals. The object of an emotion or action is not just any sensible quality, but a complex thing that usually consists of a certain set of sensible qualities and is not confused with the background or surrounding objects. Even if irrational animals were incapable of perceiving anything besides bundles of properties, as Aquinas seems to think, 45 they would nevertheless apprehend these bundles as individuals of a sort.

The two levels-perception of a certain individual as this individual and conceptualisation that is based on grasping the universal nature of the individual thing-are not exclusive in the sense that medieval authors would not have considered other kinds of perceptual processes that are related to recognition and classification. They discussed apprehension of the so-called "vague individual". When we (and in some cases animals) do not see a distant, say, human being well enough to recognise her, we nevertheless perceive in a vague way that she is a substance and an animal-supposing that she is moving. ${ }^{46}$ The fact that medieval philosophers recognised various types of

sicut videt ovis, quod hoc pilosum fulvum est lupus et hoc pilosum est canis, et unum aestimat amicum et alterum inimicum." (Albertus Magnus, De Anima, 2.3.5, 104.)

43 "Per premissa igitur haberi potest quod in brutis animalibus non est liberum arbitrium, cum ipsa rationis examinatione careant. Est tamen in eis vis concupiscibilis et vis irascibilis, cum in eis sit anima sensibilis. Est autem in eis vis concupiscibilis qua appetunt eis expedientia, vel que apparent esse expedientia. Vis irascibilis in eis est qua respuunt que eis vere vel apparenter sunt nociva; et propter huiusmodi appetitum, qui est cum electione, et propter respuitionem nocivi, que est cum fuga, videtur in eis esse discretio inter expediens et nocivum; et ita in eis videtur esse liberum arbitrium, cum eis relinquatur unum vel aliud eligere. Item. Experimento videtur idem haberi posse per hoc quod ovis eligit suum agnum inter alios agnos, et per hoc quod videtur discernere eum ab aliis. Consimile patet in canibus et apibus. Apes enim eligunt flores sibi competentiores et sibi nocivos respuunt. Solutio harum obiectionum patet per hoc quod superius dictum est in tractatu de viribus anime sensibilis. A vi enim estimativa est huiusmodi electio in brutis animalibus, et non a ratione. Tamen non est dicendum quod in eis est discretio, immo distinctio, cum discretio fit a ratione. Bruta enim distinguunt rem a re per accidentia rerum, et non discernunt. Aliquis tamen loquens improprie diceret aliquod brutum animal discernere unum ab alio, ut canem et simiam." (John Blund, Tractatus de Anima, 26.2, 226-28.)

44 "[...] estimatiua autem non apprehendit aliquod indiuiduum secundum quod est sub natura communi, set solum secundum quod est terminus aut principium alicuius actionis uel passionis, sicut ouis cognoscit hunc agnum non in quantum est hic agnus, sed in quantum est ab ea lactabilis, et hanc herbam in quantum est eius cibus [...]" (Thomas Aquinas, Sent. DA, 45/1:2.13, 122.)

${ }^{45}$ Lisska, Aquinas's Theory of Perception, 143-44, 243-49.

46 Black, “Avicenna's 'Vague Individual'," 259-92. 
cognitive processes shows how easy it was for them to think that cognition forms a kind of a scale. Perception is never just an apprehension of an isolated sensible quality, or even a set of sensible qualities. It involves different kinds of more complex features that make the external world appear to us (and to animals) as something.

\section{Two Heuristic Models}

On the basis of the foregoing, it should be clear that we are not dealing with forms of perceiving something as conceptually classified. Rather, medieval discussions are about perceiving some sensible quality $x$ in such a way that something else is apprehended alongside it. This "something else" can be another particular sensible quality, a particular substance, or any of the multiple conditions that characterise the $x$-such as movement, three-dimensionality, individuality, relevance to the well-being of the perceiver, and so forth. It is possible to make a formal description that applies to all these different types of perceiving-as:

\section{$P(x)$ as $\varphi$}

This formulation means that some subject "perceives $x$ as $\varphi^{\prime \prime}$, where $x$ is a sensible quality and $\varphi$ is any of the possible additional things that are perceived along with $x$. It should be noted that although I have mostly left aside the cases in which the intellectual powers of the soul enrich the contents of perceptual experience, the formulation itself is neutral with respect to rationality. Conceptual perception is a special case in which the additional element $\varphi$ is a universal, a natural kind, or something else that is added to perception by the intellectual power. According to some authors, rationality may also be a condition for other kinds of $\varphi \mathrm{s}$ - as, for instance, in perceiving individual substancesbut the theoretical model is not affected by these differences. ${ }^{47}$

Usually the apprehension of different kinds of $\varphi$ s was attributed to different powers of the soul. Understood in this way, perceiving-as is a kind of an information processing model. ${ }^{48}$ Information enters the soul in a rudimentary and fragmented form, and after the initial reception of raw information, various powers of the soul process it by either extracting further elements from it or by introducing new aspects. The common sense compiles a unified whole and hands it over to the imagination and the estimative power, which process the information further. This process continues until the intellect abstracts the universal essence of the thing.

There is another way to understand medieval theories, which might be called a "holistic model". Formally it might look something like this:

\section{$P(\varphi x)$}

This formulation spells things out differently than the previous one, and here the subject "perceives a $\varphi x^{\prime}$ - a dangerous wolf, sweet yellow, or crow black.

These two models bear resemblance to what Matthew Boyle has called additive and transformative models of rationality in perception. According to the former, rationality adds a conceptual layer to perception, but perception itself remains non-conceptual-

\footnotetext{
47 Aquinas' argument concerning animals' inability to perceive things as falling under a common nature is a case in point. Of the need of rationality, see also Averroes, Long Commentary on the De Anima, 2.63, 176; ibid., 2.65, 178.

48 See, e.g., Simon Kemp and Garth Fletcher, "The Medieval Theory of the Inner Senses," American Journal of Psychology 106:4 (1993): 568-69.
} 
humans and animals perceive the world more or less in the same way, but humans can conceptualise what they see in addition to seeing it. In the transformative model, by contrast, rationality transforms perception completely, which means that perception is fundamentally different in rational and irrational animals. ${ }^{49} \mathrm{~A}$ similar kind of distinction can be made in relation to different perceptual processes that are functions of the internal senses. The first model, $P(X)$ as $\varphi$, suggests that different powers of the soul do not directly change the other powers' way of operating, and that in principle the internal senses are independent elements that process information. ${ }^{50}$ In the holistic model, in contrast, perceptual acts are transformed on the very basic level by the presence of various $\varphi$ s from the other powers of the soul. Perceptual experience is either additive (internal senses either add or do not add elements to perception) or transformative (internal senses always affect the process).

The holistic model applies particularly well to theories that posit only one internal sense. I am thinking especially of Peter Olivi, who denies that we should postulate distinct powers to the soul in order to account for the various psychological functions that bring in additional $\varphi$ s at the sensory level. There is only one power, and it acts in different ways. For instance, estimation is nothing but a perception that is affected by a disposition (which can be either innate or learned). This view can be understood in such a way that there is no "pure" act of perception $P(x)$, which may or may not be accompanied by different $\varphi$ s. There is only a single act of perception, which already contains the additional elements that enrich it. Nothing has to be added to the initial perception in order to make it complex. ${ }^{51}$

It seems natural that reducing the powers of the soul entails moving from the first model to the second. However, it is not obvious that defenders of the plurality of the internal senses prefer the $P(X)$ as $\varphi$ model. Faculty psychology can be seen as an analytic project that tries to make sense of a complex psychological experience that is a unified whole at the outset. In this case, the starting point is a phenomenologically unified experience that already contains all of the different $\varphi$ s. This experience can then be analysed according to its simplest constituents, which are attributed to different powers of the soul. Understood in this way, the methodological approach of faculty psychology is not that of an information-processing model, and the division of the powers of the soul is not meant to indicate that perceptual experience is somehow divided into components that may or may not be present. To use Aristotle's famous illustration, the intellectual soul contains the sensory soul just like a square contains a triangle. The triangle is there, but one can find it only by doing some analytic work. Faculty psychology can be seen in a similar light. A unified perceptual experience contains all the $\varphi s$, but they can be singled out and distinguished from the experience only through a philosophical analysis. ${ }^{52}$

${ }^{49}$ Matthew Boyle, "Additive Theories of Rationality: A Critique," European Journal of Philosophy 24:3 (2016): 527-55. E.g., John McDowell has defended the transformative model (John McDowell, Mind and World (Cambridge, Mass./London: Harvard University Press, 1996), 4665). I am thankful to Dominik Perler for making me aware of Boyle's article.

50 One might think, for instance, that when Aquinas explicitly argues that rationality changes estimative into cogitative power and memory into reminiscence, his point is that none of the other internal senses are affected.

${ }^{51}$ For Olivi's theory, see Toivanen, Perception and the Internal Senses, 225-344.

52 For instance, Avicenna presents different divisions of the internal senses-threefold in medicine and fivefold in philosophy (Avicenna, The Canon of Medicine (Al-Qānün Fĩ'l-Tïbb), ed. L. Bakhtiar, trans. O.C. Gruner and M.H. Shah (Great Books of the Islamic World inc., 1999), 8.1, 
Some medieval authors flirted with this kind of view. For instance, when Alexander of Hales discusses the relation between the external senses and the common sense, he makes the following remark:

Moreover, it is shown that the external senses are perfected by the common sense. Namely, because the organs of the external senses are divided into two parts [...] (as in two eyes and two ears), and yet the sense object does not appear to be two but one, it is then necessary to bring it to one internal organ. Since therefore the sense object is perceived at a single moment and as one, the species is at the same time in the internal and external organ. Therefore, the external sense is perfected by the common sense, when it is perfected in the internal organ. ${ }^{53}$

This argument suggests that perceptual experience can be understood only in terms of the holistic model, at least on the very rudimentary level. We have two eyes, and therefore two $P(x)$ s take place with respect to each colourful object we see, but in our experience the object is seen as one, thanks to the common sense. Despite the fact that the common sense is distinct from the external senses, the perception of the object is unified from the beginning. We can understand that the two eyes contain one image each, but doing so requires rational inquiry. Alexander seems to apply the same approach to other internal senses as well. 54

There is one important difference between the two heuristic models. In the first model, $P(x)$ as $\varphi$, it is possible to distinguish pure perception of a single sensible quality, $P(x)$, from the subsequent processing or interpreting of the quality. In contrast, in $P\left(\varphi_{X}\right)$ the interpretative $\varphi$ is an integral part of the complex perceptual act and cannot be removed (although it can be analytically singled out). Perception is always interpretative in the sense that different $\varphi$ s are always part of perception. This means that there cannot be a perceptual act without an estimative element-estimative judgement is always present, but it is neutral when we perceive something that is not relevant to our well-being. Other internal senses are part of perception in the same way, and they form a dynamic unity. If perception is always intrinsically related to imaginative, estimative, and memorative aspects (which sometimes may be "empty"), the picture is radically different in comparison to a view in which these higher powers sometimes act and sometimes do not. This view also provides an explanation for our ability to recognise familiar things. Memory elicits an image of a previously apprehended object when we see it anew, but there is no need to give a reason for its ability to know when to act and when not to because it is always active.

Another difference between the two models is related to the additive and transformative models mentioned above. In $P(x)$ as $\varphi$, the lower levels do not necessarily depend on

$\S 557,163-64)$. This suggests that the division into different powers is an analytical tool that reflects our theoretical needs (Kaukua, "Avicenna on the Soul's Activity," 102). I have argued in favour of this interpretation in relation to Latin authors in Toivanen, "Perceptual Experience: Assembling a Medieval Puzzle" (forthcoming).

53 "Praeterea, ostenditur quod sensus particularis perficitur a sensu communi. Cum enim organa sensuum particularium bipartita sint, [...] ut in duobus oculis et duabus auribus, tamen sensibile non apparet duo, sed unum, necesse est tunc deferri ad unum organum interius; cum ergo simul tempore percipitur sensibile et ut unum, simul tempore sit species in organo interiore et exteriore: ergo perfectio sensus particularis est a sensu communi, cum perficitur in organo interiore." (Alexander of Hales, Summa Theologica, vol. 2, 1.2, q. 2, 437b; I have amended the punctuation.)

${ }^{54}$ See also Alexander of Hales, Summa Theologica, vol. 2, 1.2, q. 2, 431a-b. 
what kind of higher cognitive capacities the perceiving subject has. There might be some feedback mechanism that allows the higher powers to influence the lower ones, but this is not built into the theory. In contast, $P(\varphi x)$ entails that it is not possible to have a perceptual experience that lacks the elements that the higher powers add to it, regardless of whether they actually alter the functions of the lower powers.

At this stage it is not possible to say with certainty whether the holistic model can be applied to all medieval theories. It depends, obviously, on the details of each author's theory, and further research is needed in this regard. At any rate, the two heuristic models should be taken as two different perspectives of medieval theories of perception rather than as two conflicting theories themselves. The information processing model emphasises the physiological and psychological mechanism that brings about a perceptual experience that is enriched by various additional elements. The holistic model, on the other hand, emphasises the phenomenal experience and its unity. Although the models are not be-mutually exclusive, they serve as useful tools that enable looking at medieval theories from different perspectives.

\section{Conclusion}

By looking at medieval cognitive psychology below the level of conceptualisation or conceptual perception, it is possible to find highly sophisticated discussions on the various ways in which perceptual experience is enriched and structured. We might bundle these psychological processes under the rubric perceiving-as, but at the same time we should be careful not to attribute too strong a unity to them. After all, they are functions of different cognitive powers, not all animals have all of them, and so forth. However, medieval theories can be analysed from the viewpoint of perceptual experience, which is brought about and structured by the joint action of the internal senses. In this sense, they can be considered to be unified in a relevant way.

The main reason why I have applied the concept of perceiving-as to medieval philosophy is that it enables a reassessment of the borderline between conceptual and non-conceptual perception. In modern philosophy of mind, perceiving-as is often used in relation to conceptual perception. It tries to capture our ability to categorise things and to see the world through conceptual lenses. However, this approach leaves out many interesting aspects of perception. For instance, we humans seem to have an innate tendency (to say the least) to perceive the world around us as consisting of distinct individual things. Arguably, there is nothing conceptual in this phenomenon, although it structures our perceptions in such a way that conceptualisation becomes possible.

Medieval authors make fine-grained analyses of different elements that figure in perceptual experience, and we can ask whether some of these elements could be considered conceptual. If we adopt a strict intellectual notion of conceptuality, we might be willing to say that none of the functions discussed above count as being conceptual in the proper sense. In that case, we are led to admit that reasonably complex and sophisticated non-conceptual perception is possible. Another option is to accept a looser sense of conceptuality, which leads to hybrid notions such as proto-concepts. Either way, the grey area between the most simple perception and conceptually structured engagement with the world remains problematic and interesting, and medieval theories are helpful because they bring various non-conceptual/proto-conceptual aspects of perception to the fore. 
Medieval discussions can also help us to reconsider the distinction between humans and other animals. Almost all forms of perceiving-as discussed above were attributed to animals. According to the first heuristic model, $P(x)$ as $\varphi$, humans have an additional mental capacity that might add something to perception, namely rational knowledge of the essence of the perceived thing, conceptual classification, linguistic dimension, and so forth. But if this approach is taken strictly, as a version of the additive model, perception itself is similar in humans and animals. In contrast, the second model, $P(\varphi x)$, is easier to see as a transformative model in which the intellectual level affects perception from the very beginning. Higher types of cognitive processes cannot be distinguished from perceptual experience, which means that humans and animals might perceive the world differently-although not necessarily because this depends on what rationality is thought to add and how deep its influence is thought to go.

The impact of the approach adopted in the present chapter-taking perceiving-as in the broad sense and applying it to non-rational cognitive processes-can be fully seen only by taking into account all of the varieties of perceiving-as that were mentioned in the first section. Unfortunately, there is no room for that here. The central claim is that if we take seriously the possibility that medieval discussions can be used to develop a notion of non-conceptual perceiving-as, then it is possible to achieve a more nuanced picture of the complexity of perceptual experience. The obvious next step would be to ask what the role of rationality is in this picture. I am not going to do that here and nowparaphrasing a famous quote, at this point it would be a tiny hop for mankind, but too big a step for me. ${ }^{55}$

\section{Bibliography}

Abbott, Elizabeth. Sugar: A Bittersweet History. London/New York: Duckworth Overlook, 2008.

Albertus Magnus. De Anima. Edited by C. Stroick. Alberti Magni Opera Omnia 7/1. Aschendorff: Monasterii Westfalorum, 1968.

- — De Homine. Edited by H. Anzulewicz and J.R. Söder. Alberti Magni Opera Omnia 27/2. Aschendorff: Monasterii Westfalorum, 2008.

-_- De Sensu et Sensato. Edited by A. Borgnet. B. Alberti Magni Opera Omnia 9. Paris: Vivès, 1890.

- Physica, Libri I-IV. Edited by P. Hossfeld. Alberti Magnis Opera Omnia 4/1. Aschendorff: Monasterii Westfalorum, 1987.

Alexander of Hales. Summa Theologica. Vol. 2. Florence: Collegium S. Bonaventurae, 1928.

Anonymous. Quaestiones Super Librum De Sensu et Sensato. Paris, BNF Ms. lat. 16160, fol. 109ra-118vb.

Aristotle. The Complete Works of Aristotle. 2 vols. The Revised Oxford Translation, edited by J. Barnes. Bollingen Series 71/2. Princeton, NJ: Princeton University Press, 1984.

Averroes. Long Commentary on the De Anima of Aristotle. Translated by R.C. Taylor. New Haven/London: Yale University Press, 2009.

Avicenna. Liber de Anima Seu Sextus de Naturalibus. Edited by S. Van Riet. Vol. IV-V. Louvain/Leiden: Éditions Orientalistes/Brill, 1968.

55 This research was funded by the Academy of Finland and Stiftelsen Riksbankens Jubileumsfond. 
- C. The Canon of Medicine (AI-Qānūn Fīll-Tibb). Edited by L. Bakhtiar. Translated by O.C. Gruner and M.H. Shah. Great Books of the Islamic World inc., 1999.

Black, Deborah. "Avicenna's 'Vague Individual' and Its Impact on Medieval Latin Philosophy." In Vehicles of Transmission, Translation, and Transformation in Medieval Textual Culture, edited by R. Wisnovsky, F. Wallis, J. Furno, and C. Fraenkel, 259-92. Turnhout: Brepols Publishers, 2011.

Boyle, Matthew. "Additive Theories of Rationality: A Critique." European Journal of Philosophy 24:3 (2016): 527-55.

Dominicus Gundissalinus. Tractatus de anima. Edited by J.T. Muckle, in "The Treatise De Anima of Dominicus Gundissalinus," Mediaeval Studies 2 (1940): 23-103.

Hasse, Dag Nikolaus. Avicenna's De Anima in the Latin West: The Formation of a Peripatetic Philosophy of the Soul 1160-1300. London/Turin: The Warburg Institute/Nino Aragno Editore, 2000.

John Blund. Treatise on the Soul. Edited by D.A. Callus and R.W. Hunt. Translated by M.W. Dunne. Auctores Britannici Medii Aevi 2. Oxford: Oxford University Press, 2013.

John of la Rochelle. Summa de Anima. Edited by J.G. Bougerol. Textes Philosophiques Du Moyen Âge 19. Paris: Vrin, 1995.

- - - Tractatus de Divisione Multiplici Potentiarum Animae. Edited by P. MichaudQuantin. Textes Philosophiques Du Moyen Âge 11. Paris: Vrin, 1964.

Kaukua, Jari. "Avicenna on the Soul's Activity in Perception." In Active Perception in the History of Philosophy: From Plato to Modern Philosophy, edited by J.F. Silva and M. Yrjönsuuri, 99-116. Studies in the History of Philosophy of Mind 14. Dordrecht: Springer, 2014.

Kemp, Simon, and Fletcher, Garth. "The Medieval Theory of the Inner Senses." American Journal of Psychology 106: 4 (1993): 559-76.

Lagerlund, Henrik. "Awareness and Unity of Conscious Experience: Buridan on the Common Sense." In Questions on the Soul by John Buridan and Others: A Companion to John Buridan's Philosophy of Mind, edited by G. Klima, 149-56. HistoricalAnalytical Studies on Nature, Mind and Action 3. Dordrecht: Springer, 2017.

Lisska, Anthony J. Aquinas's Theory of Perception: An Analytic Reconstruction. Oxford: Oxford University Press, 2016.

Marmodoro, Anna. Aristotle on Perceiving Objects. Oxford: Oxford University Press, 2014.

Martino, Carla di. Ratio Particularis: Doctrines Des Senses Internes d'Avicenne À Thomas d'Aquin. Études de Philosophie Médiévale 94. Paris: Vrin, 2008.

McDowell, John. Mind and World. Cambridge, Mass./London: Harvard University Press, 1996.

Mintz, Sidney W. Sweetness and Power: The Place of Sugar in Modern History. New York: Penguin Books, 1986.

Oelze, Anselm. Theories of Animal Rationality in the Later Middle Ages. PhD Diss. Humboldt-Universität zu Berlin, 2016.

Pasnau, Robert. Thomas Aquinas on Human Nature: A Philosophical Study of Summa Theologiae Ia 75-89. Cambridge: Cambridge University Press, 2002.

Perler, Dominik. "Why Is the Sheep Afraid of the Wolf? Medieval Debates on Animal Passions." In Emotion and Cognitive Life in Medieval and Early Modern Philosophy, edited by M. Pickavé and L. Shapiro, 32-51. Oxford: Oxford University Press, 2012. 
Petrus Ioannis Olivi. Quaestiones in Secundum Librum Sententiarum. Edited by B. Jansen. Bibliotheca Franciscana Scholastica Medii Aevi 4-6. Florence: Collegium S. Bonaventurae, 1922.

Roger Bacon. Perspectiva. Edited and translated by D.C. Lindberg, in Roger Bacon and the Origins of Perspectiva in the Middle Ages. Oxford: Clarendon Press, 1996.

Silva, José Filipe \& Yrjönsuuri, Mikko (eds.). Active Perception in the History of Philosophy: From Plato to Modern Philosophy. Studies in the History of Philosophy of Mind 14. Dordrecht: Springer, 2014.

Steneck, Nicholas H. The Problem of the Internal Senses in the Fourteenth Century. PhD Diss. Ann Arbor, Michigan: UMI, 1970.

Stump, Eleonore. Aquinas. Arguments of the Philosophers. London/New York: Routledge, 2003.

Tellkamp, Jörg Alejandro. "Albert the Great on Structure and Function of the Inner Senses." In The Judeo-Christian-Islamic Heritage: Philosophical \& Theological Perspectives, edited by R.C. Taylor and A.O. Irfan, 305-24. Marquette Studies in Philosophy 75. Milwaukee: Marquette University Press, 2012.

- "Aping Logic? Albert the Great on Animal Mind and Action." In Subjectivity and Selfhood in Medieval and Early Modern Philosophy, edited by J. Kaukua and T. Ekenberg, 109-23. Studies in the History of Philosophy of Mind 16. Dordrecht: Springer, 2016.

Thomas Aquinas. Quaestiones Disputatae de Anima. Edited by B.-C. Bazán. Sancti Thomae de Aquino Opera Omnia Iussu Leonis XIII P.M. Edita 24. Rome/Paris: Commissio Leonina/Les Editions du Cerf, 1996.

- Sentencia Libri De Anima. Sancti Thomae de Aquino Opera Omnia Iussu Leonis XIII P.M. Edita 45/1. Rome/Paris: Commissio Leonina/Les Editions du Cerf, 1984

- Sentencia Libri De Sensu et Sensato. Sancti Thomae de Aquino Opera Omnia Iussu Leonis XIII P.M. Edita 45/2. Rome/Paris: Commissio Leonina/Vrin, 1985. Summa Theologiae. Edited by P. Caramello. Turin: Marietti, 1948-50.

Toivanen, Juhana. Perception and the Internal Senses: Peter of John Olivi on the Cognitive Functions of the Sensitive Soul. Leiden/Boston: Brill, 2013.

"Peter Olivi on Internal Senses." British Journal for the History of Philosophy 15:3 (2007): 427-54.

William of Auvergne. De Anima. Edited by F. Hotot. Guilielmi Alverni Opera Omnia, vol. 2. Paris: Andreas Pralard, 1674; reprint Frankfurt: Minerva, 1963.

The Soul. Translated by R.J. Teske. Milwaukee: Marquette University Press, 2000.

Yrjönsuuri, Mikko. "Seeing Distance." In Active Perception in the History of Philosophy: From Plato to Modern Philosophy, edited by J.F. Silva and M. Yrjönsuuri, 187-206. Studies in the History of Philosophy of Mind 14. Dordrecht: Springer, 2014. 